\title{
What Competencies Should Directors Possess? Malaysia Perspective
}

\author{
Wan Fauziah Wan Yusoff \\ Faculty of Technology Management and Business, Universiti Tun Hussein Onn Malaysia \\ 86400 Parit Raja, Batu Pahat, Johor, Malaysia \\ Tel: 60-7-453-3922_E-mail: fauziahy@uthm.edu.my \\ Anona Amrstrong \\ Victoria Law School, Faculty of Business and Law, Victoria University \\ Melbourne, Australia \\ Tel: 61-3-9919-6155 E-mail: anona@vu.edu.au
}

Received: August 5, 2011

Accepted: October 10, 2011

Published: January 16, 2012

doi:10.5539/ijbm.v7n2p142

URL: http://dx.doi.org/10.5539/ijbm.v7n2p142

\begin{abstract}
Directors' competencies are seeing to be of importance to corporate governance. As this issue has not yet being studied extensively in Malaysia, this study determines the key competencies of Malaysian company's directors using qualitative approach involving two stages of Delphi Technique. In the first stage all information pertaining to directors' competences in the literature had been reviewed. In the second stage, the key competencies identified in stage one were the criteria for developing a semi structured questionnaire. Participants were asked to rank the competencies in term of their importance for directors' performance. Based on personel interviews with 41 participants eight types of competencies were found to be essential for Malaysian companies' directors. Financial competencies received the highest responses, followed by corporate planning, business forecasting, legal, risk management, marketing, human resource and international business. This paper provides important evidence to support the conclusions drawn from the study about the importance of relevant directors' competencies for board and corporate effectiveness.
\end{abstract}

Keywords: Competencies, Company directors, Board effectiveness, Corporate governance

\section{Introduction}

Over the last two decades business environment has progressively seen the emergence of the knowledge-based fast-changing, technology intensive company in which investments in human resource, information technology and research and development have become essential in order to strengthen the firm's competitive position and ensure its future viability. As a consequences companies' directors'jobs today are becoming more challenging. They are called on to choose strategic and tactical initiatives to address emerging opportunities and challenges under circumstances in which the ultimate outcomes of decisions are largely unpredictable. A director's position is more difficult because they have to deal with a wider variety of issues, there will be less time to study the issues, decisions must be made more quickly, and they need to make company's decisions that involve a greater degree of uncertainty and risk. To face these new challenges, directors need to quickly acquire relevant competencies to perform their roles effectively. But what competencies does a director need to possess and which competencies are the most critical?

In Malaysia, until now none of rules or guidelines of corporate governance specify competencies of company's directors. The Malaysian Companies Act (1965) for example stated age requirement for company's directors (Section 122(2) ${ }^{1}$. While, the Malaysian Code of Corporate Governance (MCCG) recommended that Malaysian listed companies should have well-balanced and effective boards of directors that are both credible and independent. The code did not specify competencies of directors (e.g. experience, qualifications and experience).

In 2002, the Kuala Lumpur Stock Exchange (KLSE) Listing Requirement required all listed companies in Malaysia to appoint at least one member of the audit committee from a qualified accountant or a person deemed to possess accounting expertise (see Para 15.10 of the KLSE Listing Requirement (Bursa Malaysia, 2002)2. However, the main focus of the requirement is to ensure the effectiveness of audit function. Likewise, the Green 
book that was developed to provide guidance for the development of effective board of directors of Government Link Companies (GLCs) is focused on the effectiveness of board of directors as a whole. It is clear that individual directors' competencies were not yet a main concern in Malaysian corporate governance development. The questions that need to be answered were: (1) what constitutes tributes of a person (in terms of competencies) to become effective Malaysian company's director? and (2) which competency is the most crucial for the effectiveness of Malaysian corporate governance and firm performance?

This paper provides findings from qualitative study on the key competencies that are essential for Malaysian companies' directors. The remainder of this paper is organized as follows. The next section discusses relevant literature on issues pertaining to directors' competencies. The third section explains the research methodology followed by a results and discussion in section four. This paper ends with conclusion and recommendation of the research.

\section{Literature review}

\subsection{Definition and classification of competencies}

The term 'competence' originates from the Latin verb 'competere' which means 'to be suitable' (Nordhaung, 1993). Psychologists define "competency" as an underlying motive, trait or skill that leads to superior job performance. It is "underlying" in the sense that it is a motivator of behaviour, and people who have the competency may not even be aware that it is why they are effective on the job (Werner, 1994; Boyatzis, 2008). Generally, according to Boyatzis (2008) competencies can be defined as a person's capabilities or abilities to perform specified tasks. Specifically he divided competencies into three clusters that distinguished outstanding performance: expertise and experience; knowledge and basic cognitive competencies (skills) such as analytical thinking skills. Competencies, also described as characteristics of a person, which result in efficient work performance include certain personal traits, behaviors, skills, values, and knowledge which result in venture birth, survival and/or growth" (Garrat, 2005; Jokinen, 2005; Boyatzis, 2008). The definitions imply that although various definitions of competencies are found in the literature, generally competencies focus on what is expected of a person in the workplace and his or her ability to transfer and apply knowledge and skills to their work. For the purpose of this study competencies are defined as general, functional and specific knowledge, skills, and educational qualification that are necessary to enable directors to perform their roles effectively.

\subsection{The main outcomes of previous research}

The literature of corporate governance lays great store on board procedures, emphasizing the importance of directors' competencies. Research published over the last 30 years or so shows us that directors appear to require various clusters of competencies. For example, an earlier study by Hambrick and Manson (1984) revealed two types of essential competencies for top management team (TMT) including a company's directors are functional knowledge and firm-specific knowledge. Functional knowledge refer to knowledge in finance, accounting, legal, marketing and economics (Hambrick \& Manson, 1984; Forbes \& Milliken, 1999; Carmeli, 2006), and firm-specific knowledge relates to detail information about the firm and its operation (Hambrick \& Manson, 1984).

The awareness of the importance of directors' competencies in the world has been significantly increasing. The beginning of the study of competences started in the United Kingdom (UK) upon the establishment of Cadbury Report in 1992. Following this, in 1996 the UK government commissioned a research project conducted by a team from Henley Management College under the direction of the Institute of Directors (IOD) to recommend the necessary competencies of UK directors. Based on their survey ten competencies that were rated relevant for UK directors included: integrity, listening skills, motivation of others, persuasiveness, motivation, resilience, decisiveness, determination, sensitivity and energy (Dulewicz \& Gay, 1997). The results were then used by IOD in developing a set of standards for good director level practices. Since then, various individuals or institutional have explored the importance of competencies for company's directors. In the United Stated of America (US) financial expertise has been found to be positively associated with company performance. For instance, three different studies revealing similar results found that directors' who had reasonable financial backgrounds are more effective in providing internal control system mechanisms to control firm performance (Conger \& Ready, 2004; Kor \& Sundaramuthy, 2008; Ingley \& Walt, 2008). Particularly, a CEO who had a comprehensive understanding of financial statements was found to be able to monitor company accounting methods and internal control system effectively (Conger \& Ready, 2004).

In addition to financial competencies, Jeanjean and Stolowy (2008) contended that directors also needed other types business knowledge including legal knowledge, business strategy, technology, society, government policy, and firm operation. According to Andarajah (2001) and Sulaiman (2001) directors who have reasonable legal knowledge are more accountable to their jobs and they can prevent any breach of such law within the company. 
For instance, Caligiuri and Di Santo (2001) have approached the desired competencies from a company perspective including ability to transact business in another country, ability to change leadership style based on the situation, knowledge of the company's worldwide business structure, knowledge of professional contacts worldwide, knowledge of international business issues, openness, flexibility, and ethnocentrism. Carter and Lorsch (2004) review of earlier literature and concluded that boards of directors who possess various business competencies have more knowledge and understanding on current business environment and therefore enable to protect the company by providing clear decision on 'market' opportunities.

Other studies found that directors who possesses relevant business knowledge and skills play more active roles in a boardroom particularly in providing relevant input into strategic decision-making and forecasting future business for their companies (Mangena \& Pike, 2005; McDonagh, 2006; Daniel, Tanja, \& Utz, 2007). Nevertheless, it was argued that certain critical areas such as strategy formulation, change management, employee relations and organisation development were often overlooked (Conger \& Lawler, 2001). These leave big gaps in boardroom expertise because many boards of directors define these issues as being beyond the board's domain. However, because of the complexity of most business, it is impossible for any director to possess all of the competencies to come before boards. Therefore, Conger and Lawler (2009) suggested directors should possess competencies that are relevant to company activities. Generally, selection of relevant competencies has generated much argument since the relevance of competencies is commonly seen to vary with the task and companies. Based on the above reviews it is postulated that directors' competencies identified in the literature are also important for Malaysian companies' directors.

\section{Methodology}

This study used a qualitative approach involving top 100 Malaysian companies' directors. To ensure the authenticity of their stances, respondents were selected using purpose sampling based on their positions, qualifications, affiliations, length of working experience and their expertise in the areas of corporate governance. The names and affiliations were identified from the internet. Two hundred and fifty (250) directors were approached by email or telephone, but only 41 agreed to participate. The participants were from four categories namely; chairman (24.4\%), chief executive officer $(29.3 \%)$, independent directors $(26.8 \%)$ and representative of Malaysian corporate governance organizations (19.5\%). Based on Marshall and Rossman (2006) they are considered as groups 'elite' because they are influential, prominent and well-informed, and have in-depth knowledge of the subject. Therefore, they can provide rich information for the study.

The data of this study were obtained and analysed through Delphi technique. Two stages of Delphi technique were performed in this study. First, a 'pre Delphi technique process' acting as preliminary data/evidence gathering in regards to directors' competencies. The second stage, 'during and post Delphi technique process' involved two rounds, including gathering information, developing and confirming themes and confirming factors. The procedural steps in conducting the Delphi technique is illustrated in Figure 1.

The data obtained from semi-structured interviews were recorded onto a pre-formatted form. The data were arranged manually according to the themes which were compared with the literature on directors' competencies. Then, the themes and indicators were calculated based on frequency counts. This helped to identify the most important competencies of Malaysian companies' directors.

\section{Results and discussions}

\subsection{Participants' Descriptions}

Table 1 shows the backgrounds of the participants in this study. Generally, participants of this study were aged between 39 and 76 years, with an average of 55.83 years. The independent directors' and chairman's ages were found to be slightly greater than those of the CEOs and the representatives of Malaysian corporate governance organisations. This implies that both the chairmen and the independent directors in this study are the senior individuals in the Malaysian corporate sector.

The majority of the participants were men and only two women; both representing Malaysian corporate governance organisations. A lower percentage of women participants in this study reflect the scarcity of female representation on the Malaysian PLCs' boards. In terms of experience in corporate management, the chairmen were found to be the most experienced group of participants in this study with an average of 17.8 years' services. The independent directors, CEOs and representatives of Malaysian corporate governance organisations also had substantial length of service in corporate management of between 9 and 11 years. These results imply that all participants in this study were experienced directors.

In relation to ethnic groups, the majority of participants in this study were Malay ${ }^{3}$. Only five were Chinese directors and four Indian. Two reasons were identified for the low number of Chinese and Indian participants in 
this study. First, it was difficult to persuade Chinese directors to participate in this study. Although 60 letters were sent to Chinese directors, the majority of them were not interested in participating, as they were too busy or not willing to disclose information about their companies. In the case of Indian directors, the number was low due to a low percentage of Indian directors appearing in the top 100 Malaysian PLCs' boards.

Based on participants' demographic characteristics, all participants in this study can be considered well informed and experience individuals on the Malaysian corporate environment and therefore, they had provided valuable information for this study.

\subsection{Companies descriptions}

Table 2 shows descriptions of the top 100 Malaysian PLCs based on nine industry sectors. Thirty-two percent $(32 \%)$ of the companies were classified as the trading and services industry, fifteen percent $(15 \%)$ of the companies were from finance industry, twelve percent (12\%) industrial product industry, ten percent (10\%) from the plantation industry, nine percent $(9 \%)$ consumer product industry and so on. This distribution shows that the trading and services industry is the largest industry in Malaysia, followed by finance, industrial product and plantation.

\subsection{Essential competencies for directors}

Increasing challenges and changing business landscapes require a different set of directors' competencies to be effective. Based on the frequency counts analysis as in Figure 2 eight (8) types of competencies were ranked to be necessary and significant for Malaysian company's directors. Specifically, finance and accounting knowledge was rank to be the most essential competencies for directors (38 responses), followed by corporate planning ( 34 responses), business forecasting (27 responses), legal knowledge ( 23 responses), risk management (21 responses), marketing (18 responses), human resource (14 responses) and international business (14 responses).

Based on Figure 2 three quarters of the participant in this study ranked finance and accounting as the most important competency for Malaysian company directors. Today, as financial aspect is the most important indicator of a company's performance, a company's directors like or not, must prepare themselves to acquire such knowledge. The simple reason because having some understanding of finance or accounting (such as accounting ratios, investors' analysis and sensitivity to financial danger signals) can assist them to be critical appraise a company's position and make effective decision. The important of financial or accounting competencies for Malaysian companies' directors were pointed out by two participants.

Without this knowledge, it is very difficult for any director to participate actively in the board meeting (Independent director).

It is not necessary for a person to become an expert. But, at least he or she should has basic financial knowledge such has $P \& L$, Balance sheet, cash flow, financial analysis (CEO).

The above finding supports previous studies (Conger \& Ready, 2004; Kor \& Sundaramuthy; Ingley \& Walt, 2008) on the importance of directors' financial or accounting competencies. This study concludes that having finance or accounting knowledge such as understanding of a company financial statements is essential to enable directors effectively monitoring their companies performance because they will have the competencies to analyse and interpret a company's financial statements and resolve related problems.

Other types of business knowledge particularly corporate planning and business forecasting are also essential to enable director plan the future of a company. This findings support earlier studies that suggest these competencies contributes to knowledge and understanding of complex business situation Carter \& Lorsch, 2004; Jeanjean \& Stolowy, 2008). Having such competencies making them more aware on the effect of changing of business environment to their companies especially avoiding their companies from any business risks.

With the increasing number of corporate frauds legal knowledge is becoming crucial for individual director. This competency is particular important to comply with investors' demand for high standard of corporate governance. This can be explained for the reason that such knowledge enables directors to be more accountable to protect shareholders' interests. This view was supported by one participant of this study who said:

Directors must be familiar with Malaysian business laws, regulations, interpretative rulings and notices, and must exercise due diligence to see that these are not violated (Independent director).

In agreement with Sulaiman (2001) and Anandarajah (2001) this study concludes that in the case of Malaysian companies directors who had reasonable legal knowledge on Malaysian business laws and other related regulations are more accountable to overcome problems related to any breach of such laws. Moreover, they should also recognize that the effectiveness of their fiduciary duties very much relate to their legal knowledge. 
The above findings supports previous studies that revealed directors need a combination of various types of competencies. For example, in accordance with Carter and Lorsch (2004), Mangena and Pike (2005), McDonagh (2006) and Daniel, Tanja and Utz (2007), this study concludes that directors who posses various types of business competencies are more competent in understanding of business in a complex situation, which then leads them to be more effective in developing a long term planning of their companies.

In fact based on analysis of 2009 annual report of the profile of 657 directors of the top 100 Malaysian companies (Table 3), the majority of directors of these companies possesses diversity of qualifications. Of the fourteen types of qualifications of the directors, four of them (finance or accounting, economic, business studies and law) clearly support findings from the interviews. The results imply that the majority of top 100 Malaysian companies have acknowledged on the importance of having diversity of competencies among their directors especially competencies related to finance and business.

\section{Conclusion and recommendation}

In summary, this study provides some evidences that to be effective Malaysian PLC's directors need to posses particular competencies that are relevant to their company's business nature. For instance, in this study, eight types of competencies (finance and accounting, corporate planning, business forecasting, legal, risk management, marketing, human resource and internal business) were ranked to be the most essential competencies for Malaysian companies' directors. The Malaysian PLCs should therefore, select the right directors with respect to these competencies. This study concludes and found some support for the contention that directors' competencies as important component for the effectiveness of the boards. The findings of this study extend prior research on corporate governance and board of directors. This extends theory on corporate governance by suggesting that directors' competencies must be considered when constructing models of board effectiveness. As this study relied on a qualitative approach, a future and quantitative study is recommended to address these issues in greater details especially to provide empirical results on the relationship between characteristics of members of boards of directors and firm financial performance. From a practical perspective, the present study provides feedback to Malaysia corporate governance regulators and policy-makers on the need for guidelines that support effective characteristics of members of boards of directors. Finally, it is hoped that the insight derived from this study has provided useful information to Malaysian firms specifically, and other contexts generally, in terms of the importance of having balanced and competent board members.

\section{References}

Andarajah, K. (2001). Corporate governance: A practical approach. Singapore: Butterworth Asia. Boyatzis, R. (2008). Competencies in the 21st century. Journal of Management Development, 27(1), 5-12.

Bursa Malaysia. (2002). KLSE Listing Requirement. [Online] Available: http://www.klse.com.my/website/bm/rules_and_regulations/listing_requirements/downloads/LR_MBSB_28Dec 06.pdf (23 Nov. 2010).

Cadbury, A. (1992). Report on the financial aspects of corporate governance. London: Gee \& Co.

Caligiuri, P., \& Di Santo, V. (2001). Global competence: what is it, and can it be developed through global assignments? Human Resource Planning, Vol. 24 No.3, pp.27-35.

Carmeli, A. (2006). The relative importance of the top management team's managerial skills. International Journal of Manpower, 27(1), 9-36. http://dx.doi.org/10.1108/01437720610652817

Carter, C. B., \& Lorsch, J. W. (2004). Back to the drawing board: Designing corporate boards for a complex world. Boston: Harvard Business School Press.

Conger, J. A., \& Lawler, E. (2001). Building a high-performing board: How to choose the right members. Business Strategy Review, 12(3), 11-19. http://dx.doi.org/10.1111/1467-8616.00179

Conger, J. A., \& Ready, D. A. (2004). Rethinking leadership competencies. Leader to Leader, 2004(32), 41-47. http://dx.doi.org/10.1002/lt1.75

Conger, J., \& Lawler, E. (2009). Sharing leadership on corporate boards: A critical requirement for teamwork at the top. [Online] Available: http://ssrn.com/paper=1313353 (15 Jan. 2011)

Daniel, K., Tanja, C. P. z. W., \& Utz, S. (2007). Effects of top management team characteristics on strategic decision making: Shifting attention to team member personalities and mediating processes. Management Decision, 45(6).

Dulewicz, V., \& Gay, K. (1997). Personal competencies for board directors: The main dimensions and role comparisons. Competencies Journal, 4(Spring)(3).

Forbes, D. P., \& Milliken, F. J. (1999). Cognition and corporate governance: understanding boards of directors 
as strategic decision group. Academic management Review, 24(3), 489-505.

Garrat, B. (2005). A portrait of professional directors: UK corporate governance in 2015. Corporate Governance: An International Review, 13(2), 122-126. http://dx.doi.org/10.1111/j.1467-8683.2005.00411.x

Hambrick, D. C., \& Mason, P. A. (1984). Upper echelons: The organization as a reflection of its top managers. Academy of Management Review, 9(2), 193-206.

Ingley, C., \& Walt, N. V. (2008). Risk management and board effectiveness. International Studies of Management \& Organisation, 38(3), 43-70. http://dx.doi.org/10.2753/IMO0020-8825380302

Jeanjean, T., \& Stolowy, H. (2008). Determinants of Board Members' Financial Expertise - Empirical Evidence from France. [Online] Available: http://ssrn.com/paper=1284506 (10 Dec 2010)

Jokinen, T. (2005). Global leadership competencies: A review and discussion. Journal of European Industrial Training, 29, 199-216. [Online] Available: http://0-www.emeraldinsight.com.library.vu.edu.au/10.1108/0309059051059108 (10 Dec 2010)

Kor , Y. Y., \& Sundaramurthy, C. (2008). Experience-based human capital and social capital of outside directors. Paper presented at Atlanta Competitive Advantage Conference 2008. [Online] Available: http://papers.ssrn.com/sol3/papers.cfm?abstract_id=1090251 (10 Dec 2010)

Malaysian Companies Act 1965. (2007). Kuala Lumpur: MDC Group of Companies.

Mangena, M., \& Pike, R. (2005). The effect of audit committee shareholding, financial expertise and size on interim financial disclosure. Accounting \& Business Research, 35(4), 327-349.

Marshall, C., \& Rossman, G. B. (2006). Designing qualitative research. (4th Ed.). Sage Publication.

McDonagh, K. J. (2006). Hospital governing boards: A study of their effectiveness in relation to organisational performance. Journal of Healthcare Management, 51(6), 377-391.

Nordhaung, O. (1993). Human capital in organisations: Competence, training and learning. Oslo, Norway: Scandinavian University Press.

Sulaiman, A. N. (2001). Directors' duties and corporate governance. Kuala Lumpur: Sweet and Maxwell Asia.

Werner, M. C. (1994). The development of generic competencies in Australia and New Zealand. Adelaide: National Centre for Vocational Education Research.

\section{Notes}

Note 1. Section 122(2) of the Companies Act - A director must be a natural person of full age, which implies the person is not less than 18 years of age and not more than 70 years old. Nevertheless, a director of a public company reaching the age of seventy (70) years old shall vacate his position and be subject to re-election by the shareholders at a general meeting with the three-quarter majority of votes.

Note 2. (1) must be a members of the Malaysian Institute of Accountants (MIA) or (ii) if he or she is not a member of MIA, must have at least 3 years' working experience and must pass the examination specified by the Malaysia Accountant Act 1967, or he or she must be a member of one of the associations of accountants specified by the Malaysia Accountant Act 1967; (iii) fulfil such other requirements as prescribed by the Bursa Malaysia such as; (a) a degree/master/PhD in accounting or finance and at least 3 years' post-qualification experience in accounting or finance; or (b) at least 7 years' experience being chief financial officer of a corporation.

Note 3. Article 160 (2) of Federal Constitution of Malaysia (2006) defined Malay as a person who professes the religion of Islam, habitually speaks the Malay language, conforms to Malay custom and-(a) was before Merdeka Day born in the Federation or in Singapore or born of parents one of whom was born in the Federation or in Singapore, or is on that day domiciled in the Federation or in Singapore; or; (b) is the issue of such a person. 
Table 1. Participants' descriptions

\begin{tabular}{|l|c|c|c|c|}
\hline \multirow{2}{*}{$\begin{array}{l}\text { Demographics } \\
\text { characteristics }\end{array}$} & $\begin{array}{c}\text { Chairman } \\
(\mathrm{N}=10)\end{array}$ & $\begin{array}{c}\mathrm{CEO} \\
(\mathrm{N}=12)\end{array}$ & $\begin{array}{c}\text { Independent } \\
\text { director (N=11) }\end{array}$ & $\begin{array}{c}\text { Others } \\
(\mathrm{N}=8)\end{array}$ \\
\hline 1. Age (years) & 61 & 47 & 62 & 54 \\
Mean & 53 & 39 & 44 & 42 \\
Minimum & 69 & 55 & 76 & 64 \\
Maximum & & & & \\
& 10 & 12 & 11 & 6 \\
2. Gender & 0 & 0 & 0 & 2 \\
Male & & & & \\
Female & & & & 11.3 \\
& 17.8 & 9.2 & 10.9 & 4 \\
3. Experience in corporate & 12.0 & 6 & 6 & 20 \\
$\quad$ management (years) & 37.0 & 16 & 16 & 6 \\
Mean & & & & 1 \\
Minimum & & 9 & 8 & \\
Maximum & 9 & 9 & 1 & \\
4. Ethnic group & 1 & 2 & \\
Malay & 0 & 1 & & \\
Chinese & & & \\
Indian & & & & \\
\hline
\end{tabular}

Table 2. Descriptions of top 100 Malaysian PLCs based on industry sector

\begin{tabular}{|l|l|c|c|}
\hline No. & \multicolumn{1}{|c|}{ Industry sector } & Number of company & Percentage \\
\hline 1 & Trading \& services & 32 & $32 \%$ \\
2 & Finance & 15 & $15 \%$ \\
3 & Industrial product & 12 & $12 \%$ \\
4 & Plantation & 10 & $10 \%$ \\
5 & Consumer product & 9 & $9 \%$ \\
6 & Property & 7 & $9 \%$ \\
7 & Construction & 5 & $7 \%$ \\
8 & Infrastructure project cos & 1 & $5 \%$ \\
9 & Technology & \multicolumn{1}{|c|}{100} & 100 \\
\hline
\end{tabular}

Table 3. Directors' educational qualification

\begin{tabular}{|c|l|r|c|}
\hline No. & \multicolumn{1}{|c|}{ Qualification } & Frequency & Percentage \\
\hline 1 & Finance or accounting & 149 & 22.7 \\
2 & Engineering & 83 & 12.6 \\
3 & Economic & 117 & 17.8 \\
4 & Business studies & 81 & 12.3 \\
5 & Law & 59 & 9.0 \\
6 & Science & 37 & 5.6 \\
7 & Commerce & 15 & 2.3 \\
8 & Art & 52 & 7.9 \\
9 & Agriculture & 13 & 2.0 \\
10 & Architecture & 6 & 0.9 \\
11 & Education & 4 & 0.6 \\
12 & Social science & 15 & 2.3 \\
13 & Defence studies & 10 & 1.5 \\
14 & Other & 16 & 2.4 \\
\hline & Total & 657 & 100 \\
\hline
\end{tabular}

Note: Data captured from the annual reports 2009 of top 100 Malaysian public listed companies 


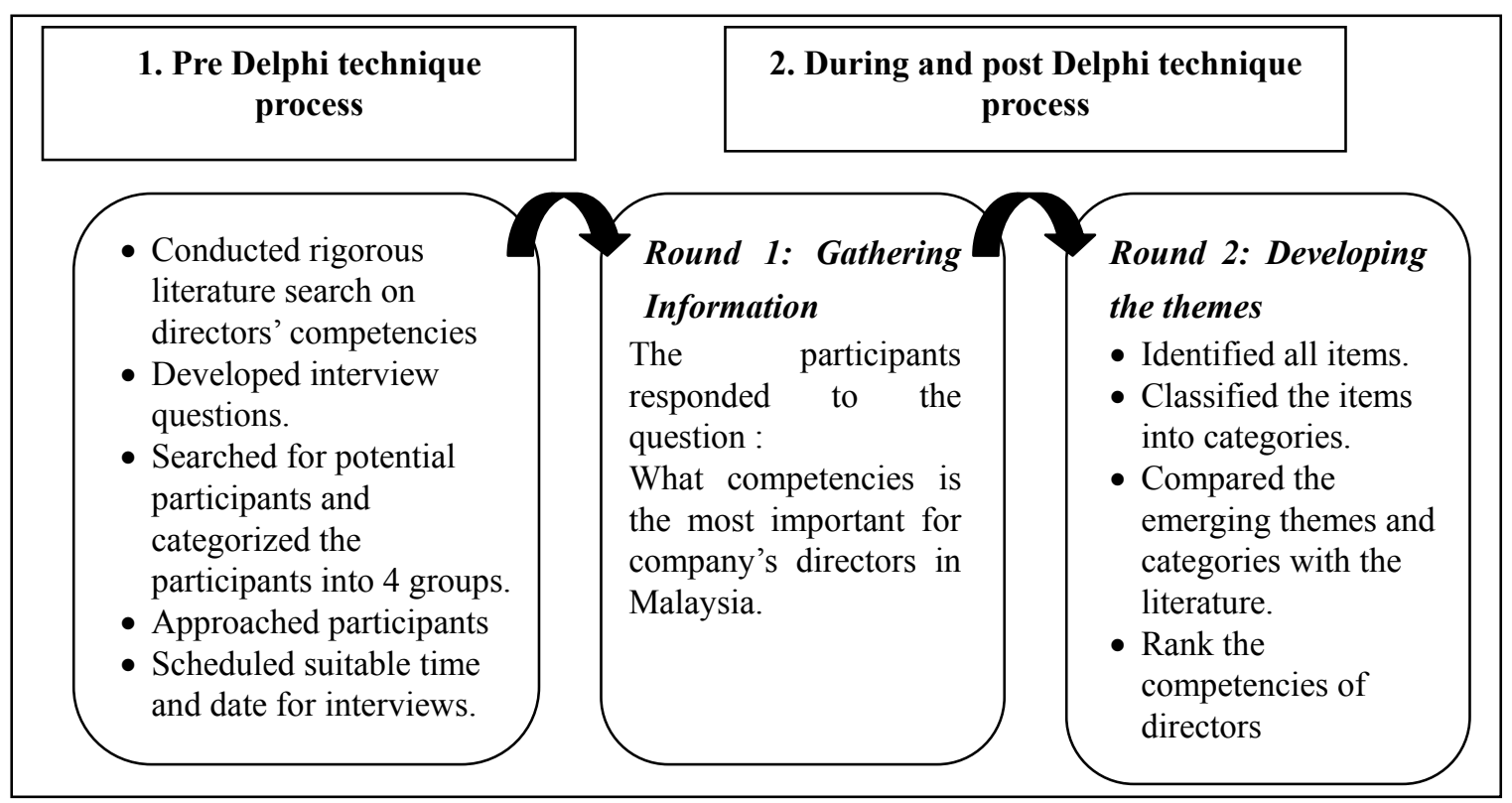

Figure 1. Two stages of Delphi Technique performed in this Study

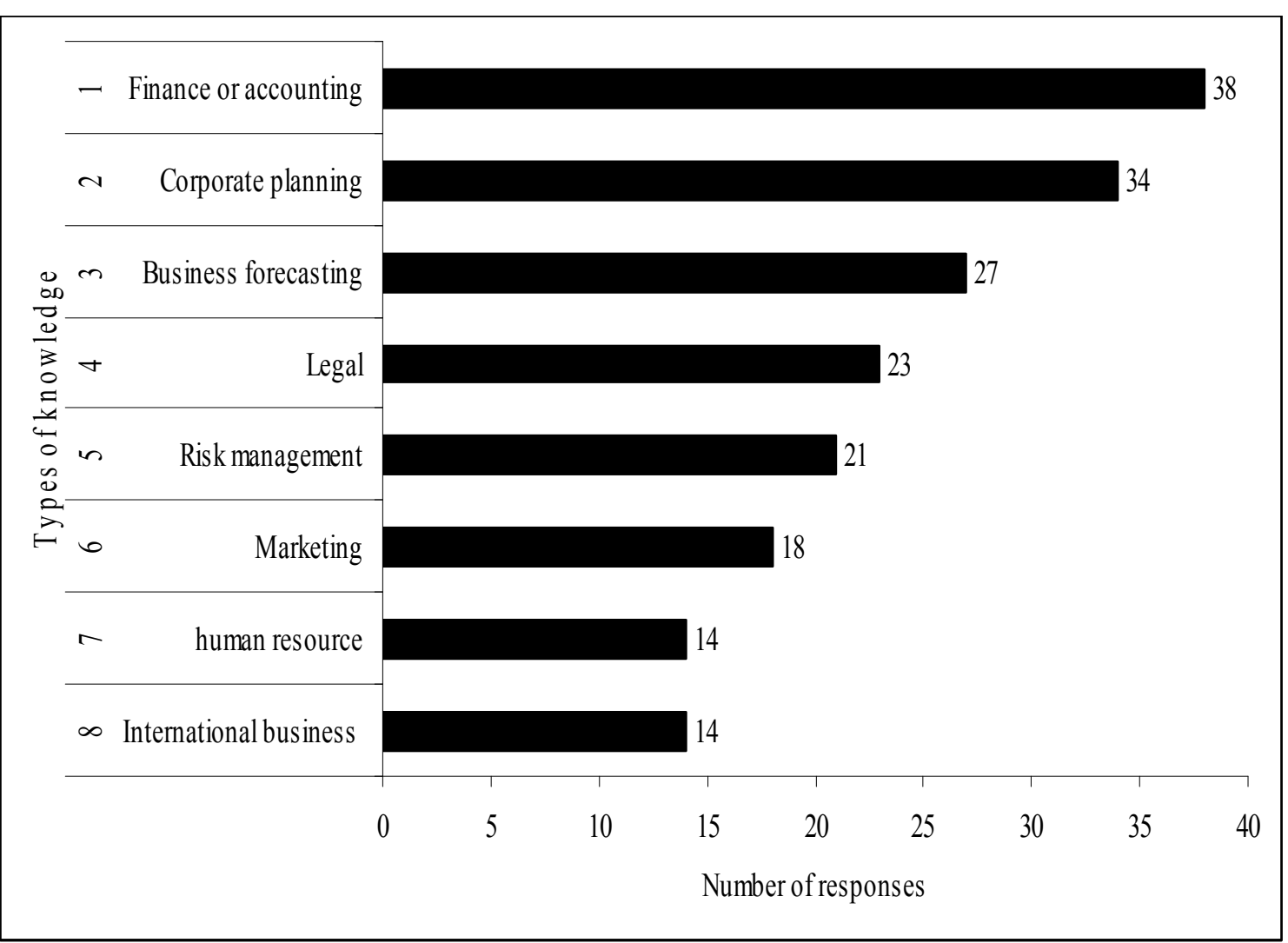

Figure 2. Eight types of essential competencies for Malaysian companies directors derived from interviews with 41 participants of this study 